\title{
SOCIAL DYNAMIC STATUS AND ITS REFLECTION ON USE OF FAMILY PLANNING METHODS IN AN INDIAN VILLAGE: THE CASE OF 'GAURA' VILLAGE (UP), INDIA
}

\author{
Vimalesh Kumar Singh \&. M. B. Singh \\ Department of Geography, Banaras Hindu University, \\ Varanasi-221005, U P India \\ singhmb@rediffmail.com
}

\begin{abstract}
Present paper aims at examining the recent transformation of the village society, which is caste ridden, conservative and sluggish to adopt new innovations. The paper is mainly based on primary data collected through interview schedules from 80 families and 123 married women respondents on stratified random basis from Gaura village of Mirzapur District, Uttar Pradesh. On the basis of social dynamic status in a rural population of Gaura village the study pinpoints that Yadav, Gupta, Lohar, and Harijan (Scheduled caste) castes are static communities while Kurmi has been found single progressive caste. Brahmin and Kumhar are categorized as retrogressive castes. The paper also highlights the position of spouse on the practice of family planning methods. This study was undertaken to assess the extent of awareness among married women towards the various aspects of family planning. It was found that majority of the respondents had knowledge and awareness about various aspects of family planning but its adoption is of low magnitude. Women were the major users of permanently contraceptives (tubectomy) as contrary to men. Some women were found with the use of oral pills but the use of loops, condom and copper-T was almost absent in the study village.
\end{abstract}

Key words: Family planning attitude, never users, contraceptives, caste, traditional social hierarchy.

\section{INTRODUCTION}

In order to understand the social structure of a village or a region, the thorough understanding of demographic aspects along with historical, cultural and economic aspects is imperative. The social dynamism reflects the capacity of any community to transform itself in response to the modern changes of the society (Sriniwas, 1969). Discrimination on the basis of caste has been common in social, economic and political sphere as well as settlement for generations (Kumar, 2008). On the basis of socio- economic status of various castes, the change in hierarchy of castes can be ascertained.

Although India was the first country to adopt family planning as a National programme during 195152 , the demographic situation in the country is still a matter of grave concern. The low use of spacing methods is reflected in untimely child bearing and short birth intervals. Wherever, services survive, women are controlled for using the family planning methods by cultural society or pressure to rebuild the population. A close organization between family planning knowledge, attitude and behavior was observed by Pandey and Singh (2001), which indicated that good awareness of adequate wealth of family planning, its efficiency and adequate source of information exercised, positive impact on developing or encouraging attitude which motivated females to adopt family planning methods. However, the recent changes in the institution of family, education and economic independence of women have affected the traditional system and brought some structural changes in the status and role of woman as a housewife in the family. The present study was conducted with an objective to study the extent of awareness of women with regard to family planning methods. One of the socio-demographic goals identified for this purpose is to achieve universal access to information/ counseling and services for fertility regulation and contraception with a wide range of choices (Ministry of Health and Family Welfare, 2000). In India as a whole, current contraceptive rate of currently married women is $56 \%$. Female sterilization, with prevalence of $37 \%$, accounted for $71 \%$ of all contraceptive use in India (International Institute for Population Sciences and ORC Macro, 2007). Still there is need to change the scenario of contraception use in India. Currently, India is the second most populous country in the world, contributing about $20 \%$ of births worldwide (World Health Organization, 2006). Also, it continued to have one of the most rapidly growing population in the world. However, third National Family Health Survey (NFHS-3) reported that fertility continues to decline in India. The current total fertility rate (TFR) of 2.7 is down slightly from 2.9 children per woman at the time of second National Family Health Survey (NFHS-2), but is still well above the replacement level of just over two children per woman (International Institute for Population Sciences and ORC Macro 2000, 2007). The National Family Welfare Programme in India has traditional sought to promote responsible and Planned Parenthood through voluntary and free 
choice of contraceptive methods best suited to individual acceptors (Ministry of Health and Family Welfare 1998). Since its inception, the programme has experienced significant growth in terms of financial investment, service delivery points, type of services, and the range of contraceptive methods offered. Since October 1997, the services and interventions under the Family Welfare Programme and the Child Survival and Safe Motherhood Programme have been integrated with the Reproductive and Child Health Programme. In the National Population Policy, 2000, the Government of India set as its immediate objective the task of addressing unmet need for contraception to achieve the medium range objective of bringing the total fertility rate down to replacement level by 2010 . In this context, the present paper reports the attitude of spouse on practice of family planning of Gaura village population of Mirzapur district, Uttar Pradesh, India.

The study has two fold objectives, which are to assess the socio-economic status of various castes especially in terms of their traditional social hierarchy and to find out the socio cultural - religious economic factors inhibiting adequate utilization of family planning.

The village Gaura is slow changing rural center depicting changes in occupation, land use and settlements. The incentives given by the government to inferior strata of population have not brought remarkable change in economic standard of the schedule castes and backward classes excepting in Kurmi caste. In this contextual basis it is hypothesized that the old established hierarchy of social status is changing and generating the new economic hierarchy; the family planning utilization is higher in socially and economically advanced castes (upper and middle castes) compared to poor and scheduled castes; and the higher the awareness about the family planning programme more is the adoption of family planning methods.

\section{STUDY AREA}

Geographically, Gaura village is located at $57^{0} 7^{\prime} \mathrm{N}$ latitude and $82^{\circ} 57^{\prime}$ 7" E longitude in Mirzapur district of Uttar Pradesh (UP), India (Fig.1). It is 8 $\mathrm{km}$ away from Chunar town, and is situated on the eastern side of National Highway No. 7, which is familiar as Varanasi to Kanyakumari road. Total population of this village is 1290 and approximately 32.17 present of the total is scheduled caste. The low literacy rate (55.81 present) was observed in this village. The village has many communities and castes but mainly belonging to Hindu religion. At the time of the survey, the village had 205 households constituted by seven Hindu castes.

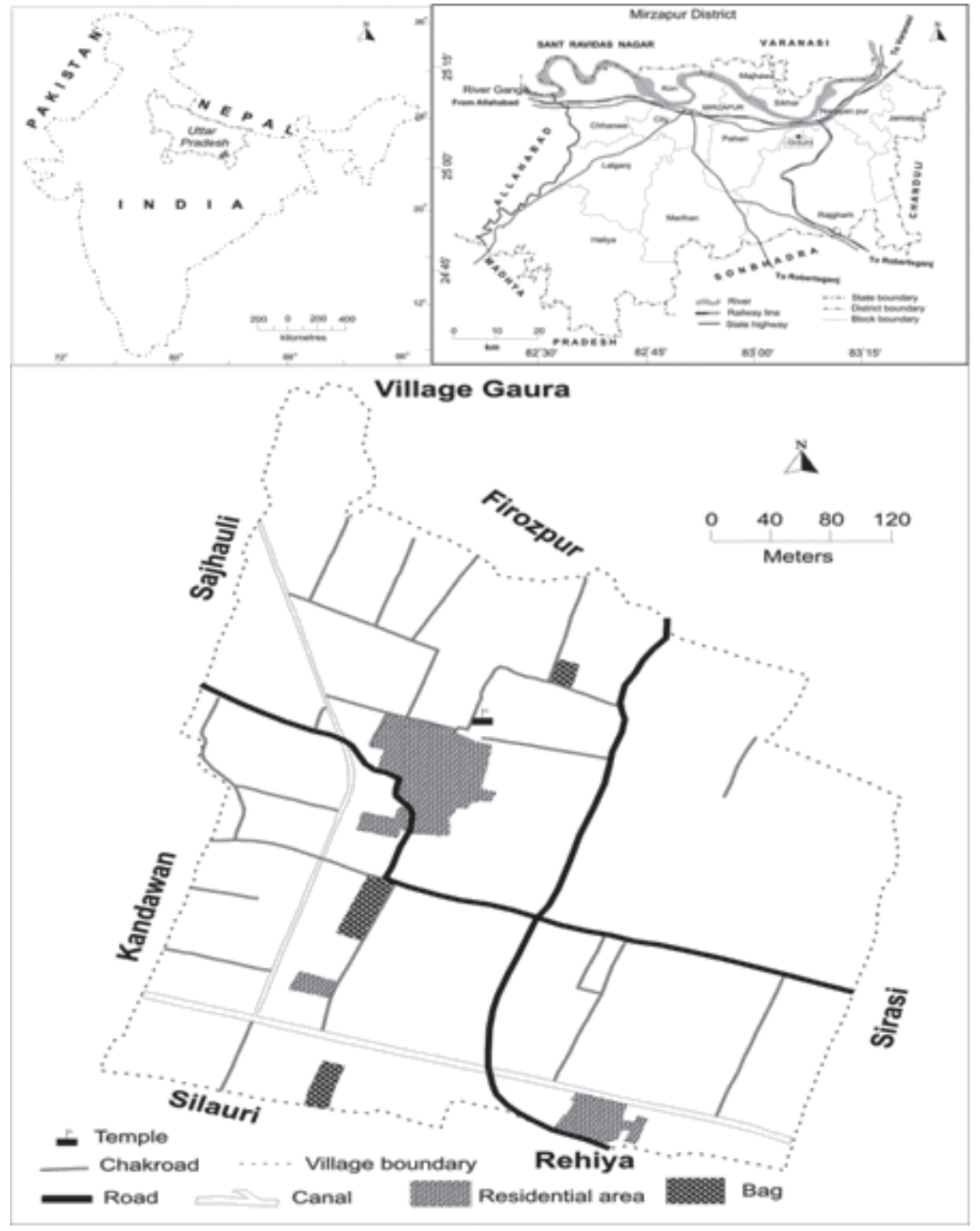

Map 1: Location of the Study Area 


\section{DATA SOURCES AND ANALYSIS}

The present study is based on both primary and secondary data. The primary information was obtained from 123 respondents of age 18 to 45 years from 80 households belonging to different caste on the basis of stratified random sampling conducted in March 2007. Married women with first child up to the age of five years were randomly selected and administered personal interview in a structured questionnaire. The information pertaining to demographic and socio-economic characteristics of households, and attitude of spouse regarding family planning acceptance was collected through in-depth interviews. Structured questionnaire was used to know about general information and awareness and knowledge regarding family planning methods, demographic, socio and economic data pertain to sex ratio, indicators have been ranked in terms of their condition. Further, composite score has been achieved by summing up the individual score of all indicators of socio-economic development.

\section{RESULT AND DISCUSSION}

Socio-economic Status by Castes

Castes play an important role to determine the level of socio-economic status of rural households in India (Yadav et al. 2003). In this table higher rank (1) has been assigned to indicate better condition in that aspect and lower rank (3) to poor condition.

Finally, composite score has been calculated to know the change in hierarchy. It is obvious from Table 1 that Brahmin, and Kurmi belong to developed caste, Yadav, Lohar and Gupta, belong

Table 1

Socio-economic status of castes

\begin{tabular}{|c|c|c|c|c|c|c|c|c|c|c|c|c|c|c|c|c|c|c|}
\hline 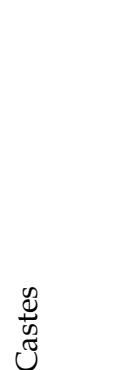 & $\begin{array}{l}\frac{0}{0} \\
0 \\
0 \\
0 \\
0 \\
0 \\
0 \\
0 \\
0 \\
0 \\
\dot{Z}\end{array}$ & 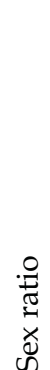 & 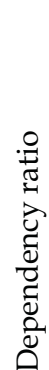 & 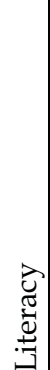 & $\begin{array}{l}0 \\
0 \\
0 \\
0 \\
0 \\
3 \\
3\end{array}$ & 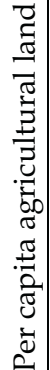 & 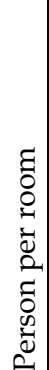 & 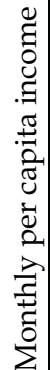 & 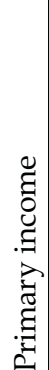 & 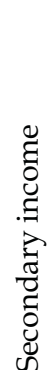 & 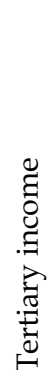 & 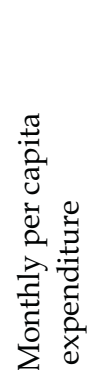 & $\begin{array}{l}\mathbf{T} \\
8 \\
0\end{array}$ & $\underset{2}{\vec{D}}$ & 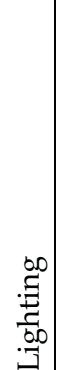 & 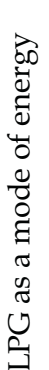 & 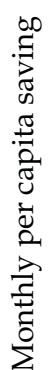 & 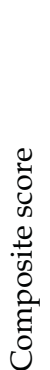 \\
\hline Brahman & 1 & 2 & 1 & 2 & 2 & 1 & 2 & 1 & 2 & 1 & 1 & 2 & 2 & 1 & 1 & 2 & 2 & 26 \\
\hline Kurmi & 1 & 2 & 3 & 1 & 2 & 2 & 1 & 1 & 1 & 1 & 1 & 1 & 2 & 1 & 1 & 1 & 1 & 23 \\
\hline Yadav & 3 & 1 & 2 & 2 & 2 & 2 & 2 & 3 & 2 & 3 & 3 & 3 & 2 & 3 & 2 & 3 & 2 & 40 \\
\hline Gupta & 2 & 1 & 2 & 2 & 2 & 2 & 2 & 2 & 2 & 2 & 2 & 2 & 2 & 2 & 1 & 2 & 2 & 32 \\
\hline Lohar & 2 & 1 & 1 & 2 & 1 & 3 & 2 & 2 & 3 & 1 & 2 & 2 & 2 & 2 & 2 & 3 & 2 & 33 \\
\hline Kumhar & 3 & 2 & 1 & 3 & 1 & 3 & 3 & 3 & 3 & 3 & 3 & 3 & 3 & 3 & 3 & 3 & 3 & 46 \\
\hline Harijan & 3 & 2 & 1 & 3 & 1 & 3 & 3 & 3 & 3 & 3 & 3 & 3 & 3 & 3 & 3 & 3 & 3 & 46 \\
\hline
\end{tabular}

Source: Field survey 2007

dependency ratio, literacy, workers, per capita agricultural land, persons/room, per capita monthly income, monthly per capita expenditure, monthly per capita saving, etc. Based on the socioeconomic conditions of the castes, the respondents were categorized into two categories, i.e. scheduled caste (SC) and non scheduled caste. Harijan represents to S.C. caste here. Further the respondents were also categorized based on their age, caste, occupation, education, income, age at marriage and age at first child birth. All socio-economic to moderately developed caste; and Kumhar and Harijan belong to underdeveloped caste.

\section{Comparative change in the hierarchy of castes}

As per one of the objectives of the study, the old established social status has been compared with the present socio-economic status and subsequently three categories of castes have been identified during the survey (Table 2). 
Table 2

Relative change in status of castes

\begin{tabular}{|l|c|c|c|}
\hline \multicolumn{1}{|c|}{ Castes } & Traditional Rank & Composite Rank & Status \\
\hline Brahmin & 1 & 2 & Retrogressive \\
\hline Kurmi & 2 & 1 & Progressive \\
\hline Yadav & 2 & 2 & static \\
\hline Gupta & 2 & 2 & Static \\
\hline Lohar & 2 & 2 & Static \\
\hline Kumhar & 2 & 3 & Retrogressive \\
\hline Harijan & 3 & 3 & static \\
\hline
\end{tabular}

Source: Field survey 2007

\section{Retrogressive castes}

The rank of socially high caste such as Brahmin has downed from 1st to 2 nd or upper class to middle class in the village. It has, thus, shown a decline from its top status recognized on the basis of socioeconomic-religious parameters. Brahmins are now changing their age-old religious livelihood. However, in the process of change, they are not able to keep their top status but have slipped downwards, consequently recognised as retrogressive caste. Similarly, Kumhar has also sliped in their hierarchy e.g. from 2 nd to $3 \mathrm{rd}$. They are also loosing their traditional occupation due to modernization and not switched over to another profession satisfactorily. As such their position is similar to Brahmin.

\section{Static castes}

Yadav, Lohar and Gupta, castes have maintained their traditional rank of hierarchy. These castes belonged to 2nd rank where as Harijan caste belonged to $3 \mathrm{rd}$ rank, which revealed their traditional social status

\section{Progressive castes}

Kurmi caste has made noticeable progress in their social and economic status. The rank of Kurmi caste has changed and superseded to Brahmin from 2nd to 1st caste. Yadav, Gupta, Lohar and Harijan did not reveal any change in their social and economic position. They have maintained same position of 2nd and 3rd rank of hierarchy. Therefore, it is evident from the previous discussion that no conspicuous change has been experienced in the social status of middle and lower castes especially Yadav, Gupta Lohar, and Harijan, in this village. They have poor standard of living so far. With the low progress in economy and slow increase in education, the middle and lower castes have not marked reputable position in the village society. Although the inhuman social behavior, which was a blot on Indian society, has been substantially weeded out in the village. Lower castes now live in agreement with upper castes. All the changes are reflected in the social system of village Gaura. In the village, untouchability is nearly abolished. Education, infrastructure, influence of district headquarters 'Mirzapur', $35 \mathrm{~km}$ away from the village under study, and any political advancement in the village have not contributed substantially to the change in the status of the lower and middle castes. It seems that the efforts made by the state and the central governments have not brought fruitful results in ameliorating the condition of down trodden of the society.

Use of Family Planning Methods and Awareness

The institution of marriage defines and circumscribes the life of a woman as wife, a mother and a house maker. Thus it is fairly common for both men and women to discuss family planning. Lack of time, education and awareness are deeprooted constraints for women to perform their multi-dimensional role. The socio-economic characteristics of women respondent's studied for this purpose are given in table 3.

The maximum number $(47.97 \%)$ of women were in the age group of 18 to 25 years and majority of them were literate $(92.69 \%)$, housewives $(75.60 \%)$ and belonged to nuclear families (78.75\%). Most of the women $(58.53 \%)$ were married at the age between 18 and 25 years and maximum $(45.52 \%)$ had their first child at the age range of 25 to 30 years. An analysis of age at marriage and birth of first child evinced that substantial number of marriages and births of first child was performed too early (below 18 years) and before 25 years of age, which are not conducive atmosphere for safe mother and childhood. A study by Kaur and Patnaik 
Table 3

Socio-economic characteristics of respondents

\begin{tabular}{|c|c|c|}
\hline Variables & $\begin{array}{c}\text { Number of female } \\
\text { respondents }(\mathrm{N}=123)\end{array}$ & $\%$ \\
\hline \multicolumn{3}{|l|}{ 1. Age Group (in years) } \\
\hline 18 to 25 & 59 & 47.97 \\
\hline 25 to 30 & 28 & 22.76 \\
\hline 30 to 40 & 22 & 17.89 \\
\hline 40 to 45 & 14 & 11.38 \\
\hline \multicolumn{3}{|l|}{ 2. Education level } \\
\hline Illiterate & 09 & 7.31 \\
\hline Educated primary level & 11 & 8.94 \\
\hline Educated middle level & 20 & 16.26 \\
\hline Educated high school & 31 & 25.20 \\
\hline Under graduate & 27 & 21.95 \\
\hline Graduate and above & 25 & 20.32 \\
\hline \multicolumn{3}{|l|}{ 3. Occupation } \\
\hline Housewife & 93 & 75.60 \\
\hline Labourer & 30 & 24.39 \\
\hline \multicolumn{3}{|l|}{ 4. Family type } \\
\hline Nuclear & 63 & 78.75 \\
\hline Joint & 17 & 21.25 \\
\hline \multicolumn{3}{|c|}{ 5. Age at marriage (in years) } \\
\hline Below 18 & 21 & 17.07 \\
\hline 18 to 25 & 72 & 58.53 \\
\hline 25 to 30 & 30 & 24.39 \\
\hline \multicolumn{3}{|c|}{ 6. Age at Birth of first child (in years) } \\
\hline Below 18 & 8 & 6.50 \\
\hline 18 to 25 & 39 & 31.70 \\
\hline 25 to 30 & 56 & 45.52 \\
\hline Above 30 & 20 & 16.25 \\
\hline
\end{tabular}

Source: Field survey 2007

(1999) indicated that literacy in general and female literacy in particular exerted a strong influence on contraceptive use. Higher literacy promoted declines in fertility and child mortality. Akin to education, awareness plays an important role in motivating females to have a favourable attitude towards family planning programme and to adopt family planning methods. In the present study, majority of the women (92.68) knew about family planning programme and different types of contraceptive methods. Majority of the respondents were aware about the tubectomy (117), abortion (81), chemical method (oral pills), and mechanical method of family planning (loop and condoms). The reason behind high degree of awareness might be that the respondents were influenced by the effect of mass media (Television and Radio). Awareness about the condom use was low which might be attributed to the fact that there were no open discussions about this matter at home. Jain and Nag (1999) found that the knowledge about one or more contraceptives and current contraceptive uses was found to be in proportion of 78.8 and 24.2 percent, respectively. The use of contraceptives is regarded as being the wife's responsibility. Ringheim (1993) reported that globally, men have not shared equally with women the responsibility of fertility regulation. Family planning efforts have been directed almost exclusively towards women. The lack of male involvement also reflects the limited options available for women. A study by Sinha et al. (2001) revealed that husband's willingness for contraception and improper uses of condoms were responsible for one third of all unwanted pregnancies. The distribution of respondents 
according to their use of contraceptives is given in Table 4 . awareness about the family planning programme is common in all castes of the study area excepting

Table 4

Knowledge and awareness of birth control measures

\begin{tabular}{|l|c|c|}
\hline \multicolumn{1}{|c|}{ Variables } & Number of respondents (N=123) & $\%$ \\
\hline Knowledge of birth control measures & 114 & 92.68 \\
\hline Awareness regarding birth control methods & 56 & 45.52 \\
\hline Mechanical (copper-T, Condoms) & 80 & 65.04 \\
\hline Chemical (Oral pills) & 117 & 95.12 \\
\hline Sterilization & 81 & 65.85 \\
\hline Abortion & \multicolumn{2}{|c|}{} \\
\hline Usage of birth control methods & 23 & 50.00 \\
\hline Use of oral pills & 21 & 45.65 \\
\hline Use of tubectomy & 2 & 4.35 \\
\hline Abortion & \multicolumn{2}{|c|}{} \\
\hline
\end{tabular}

\section{Source: Field survey 2007}

In the present study merely $37.39 \%$ women adopted some kind of birth control methods. The findings suggested that women were the main adaptors of contraceptives whereas men played lesser role. Tubectomy (nusbandi) was the well known and was used by 45.65 percent women whereas Oral pills were used by 50.0 percent women. Use of loops

Kumhar that are neither awared nor users of any family planning programme.

Cent percent awareness had been found in Brahmin, Gupta and Yadav castes followed by Kurmi. Little bit lower awareness was observed in Lohar and Harijan castes. Advanced castes such as Brahmin,

Table 5

Awareness about family planning programme

\begin{tabular}{|l|c|c|c|c|c|}
\hline \multicolumn{1}{|c|}{ Caste } & Total no. of respondents & Yes & $\%$ & No & $\%$ \\
\hline Brahmin & 45 & 45 & 100 & - & - \\
\hline Kurmi & 40 & 38 & 95.0 & 2 & 5.00 \\
\hline Gupta & 2 & 2 & 100 & - & - \\
\hline Yadav & 4 & 4 & 100 & - & - \\
\hline Lohar & 6 & 5 & 83.33 & 1 & 16.33 \\
\hline Kumhar & 3 & - & - & 3 & 100 \\
\hline Harijan & 23 & 20 & 86.95 & 3 & 13.05 \\
\hline Total & 123 & 114 & 92.68 & 9 & 7.32 \\
\hline
\end{tabular}

Source: personal survey based data

and condoms was absent in the studied women. The findings of the present study were compared with the data available from National Family Health Survey (NFHS 1998) and it was found that the use of family planning method is lower than all India figures (48.2\%). Exposure to the electronic mass media (radio, television and internet) has a large and positive effect on the current contraceptive use and intended future use of contraception (Retherford and Misra 1997).

The survey pertaining to caste wise awareness and use of family planning programme reports that
Kurmi and Gupta are awared about almost all methods of family planning while relatively poor castes of the village knew only oral pills, tubectomy and abortion method to limit the family size. As far as the caste wise use of family planning method is concerned it is unique that Brahmin that are known for their high social status witnessed only 26.66 percent users of their total respondents followed by Harijan (13.05\%). Guptas, Lohars, Kurmi and Yadavs had highest proportion of users respondents. 
Table 6

Awareness about the family planning methods

\begin{tabular}{|c|c|c|c|c|c|}
\hline Caste & Copper- T & Oral pills & Tubectomy & Abortion & Condom \\
\hline Brahmin & 6 & 27 & 45 & 29 & - \\
\hline Kurmi & 32 & 40 & 40 & 40 & 15 \\
\hline Gupta & 2 & 2 & 2 & 2 & 1 \\
\hline Yadav & - & 1 & 4 & 3 & - \\
\hline Lohar & - & 4 & 6 & 4 & - \\
\hline Kumhar & - & - & - & - & - \\
\hline Harijan & - & 6 & 20 & 3 & - \\
\hline Total & 40 & 80 & 117 & 81 & 16 \\
\hline
\end{tabular}

Source: Field survey 2007

The perusal of education wise use of family planning methods indicated that illiterate as well as primary level literate women had used only tubectomy for birth control. However among highly literate (intermediate and graduate) women communities have contributed to low contraceptive acceptance (Nag 1984).

In the present study maximum $24.67 \%$ respondents of the never users mentioned fear of side effects of

Table 7

Caste wise use of family planning methods

\begin{tabular}{|l|c|c|c|c|c|}
\hline \multicolumn{1}{|c|}{ Caste } & Coper- T & Oral pills & Tubectomy & Abortion & \% of users \\
\hline Brahmin & - & 8 & 4 & - & 26.66 \\
\hline Kurmi & - & 14 & 7 & 2 & 57.50 \\
\hline Gupta & - & 1 & 1 & - & 100.0 \\
\hline Yadav & - & - & 2 & - & 50.0 \\
\hline Lohar & - & - & 4 & - & 66.67 \\
\hline Kumhar & - & - & - & - & - \\
\hline Harijan & - & - & 3 & - & 13.05 \\
\hline Total & - & 23 & 21 & 2 & 37.39 \\
\hline
\end{tabular}

Source: Field survey 2007

use of oral pills, tubectomy and abortion is common.

Table 9 portrays the reasons of not adopting any family planning method by never users $(n=77)$. Rumours which are told and retold through the the family planning methods as an important reason for non adoption. No knowledge appeared the second reason followed by opposition from husband side. Ignorance which is fourth reason indicated the fear of procedure and anesthesia as

Table 8

Education wise use of family planning methods

\begin{tabular}{|l|c|c|c|c|}
\hline \multicolumn{1}{|c|}{ Education } & Oral pills & Tubectomy & Abortion & \% of users \\
\hline Illiterate & - & 3 & - & 6.52 \\
\hline Primary & - & 2 & - & \multirow{2}{*}{93.48} \\
\hline Middle & 2 & 4 & - & \\
\hline High school & 3 & 4 & - & \\
\hline Intermediate & 10 & 1 & 3 & 37.39 \\
\hline Graduates & 8 & 7 & 4 & \\
\hline Total & 23 & 21 & & \\
\hline
\end{tabular}


the reason for non adoption of family planning programme. Opposition of family members has also been one of the reasons. Sexual dissatisfaction may be one component of other causes of non adoption. In Nepal also concern about surgery and users. DHS reports from Bangladesh, Nigeria, Pakistan and Senegal revealed that more than 10\% of the women with unmet need who did not intend to use contraception cited religious objections in Muslim living areas.

Table 9

Never users of contraception by reasons

\begin{tabular}{|l|c|c|}
\hline \multicolumn{1}{|c|}{ Reasons for never use of contraception* } & No. & \% \\
\hline Scared of side effects & 19 & 24.67 \\
\hline Ignorance (About use) & 12 & 15.58 \\
\hline No Knowledge & 18 & 23.38 \\
\hline Opposition from other family members & 9 & 11.68 \\
\hline Opposition from husband & 15 & 19.48 \\
\hline Other causes & 4 & 5.21 \\
\hline Total & 77 & 100 \\
\hline
\end{tabular}

Source: Field survey 2007

its complications was cited as an important reason for non adoption of sterilization (Stash 1995, and Khan et al. 1985). Also the fact that sterilization led to weakness $(56.86 \%$ ) was also observed in Nepal (Shrestha et al., 1988). Khan et al. 1985) also made similar observations in U.P.

The village under study has no Muslim population as such religion reason for opposing birth control method is absent. Muslims are less likely to be ever
Caste wise breakup of never users of family planning methods is presented in table 10. Kumhar, traditionally known as earthen pot maker is at the top in never use category followed by Harijan (poor caste) and Brahmin (most advanced caste). Gupta famous as business community is not the part of never users category. Kurmi, Lohar and Yadav form the moderate category of never users. Side effects, ignorance and no knowledge reasons responsible for never users are common in Brahmin, Kurmi

Table 10

Caste wise never users of family planning methods by reasons

\begin{tabular}{|c|c|c|c|c|c|c|c|c|}
\hline \multirow{2}{*}{$\begin{array}{l}\text { Reasons of } \\
\text { never use }\end{array}$} & \multicolumn{7}{|c|}{ Caste wise respondents } & \multirow{2}{*}{$\begin{array}{l}\% \text { of } \\
\text { never } \\
\text { users by } \\
\text { causes }\end{array}$} \\
\hline & Brahmin & Kurmi & Gupta & Yadav & Lohar & Kumhar & Harijan & \\
\hline Side effects & 4 & 7 & - & 1 & - & - & 7 & 24.67 \\
\hline $\begin{array}{l}\text { Ignore (about } \\
\text { use) }\end{array}$ & 6 & 6 & - & - & - & - & - & 15.58 \\
\hline $\begin{array}{l}\text { No } \\
\text { knowledge }\end{array}$ & - & 4 & - & - & 1 & 3 & 10 & 23.38 \\
\hline $\begin{array}{l}\text { Opposition of } \\
\text { family } \\
\text { members }\end{array}$ & 9 & - & - & - & - & - & - & 11.68 \\
\hline $\begin{array}{l}\text { Opposition of } \\
\text { husband }\end{array}$ & 12 & - & - & - & 1 & - & 2 & 19.48 \\
\hline Other causes & 2 & - & - & 1 & - & & 1 & 5.21 \\
\hline Total & 33 & 17 & - & 2 & 2 & 3 & 20 & 62.61 \\
\hline $\begin{array}{l}\% \text { of caste } \\
\text { wise never } \\
\text { users }\end{array}$ & 73.34 & 42.50 & - & 50.00 & 33.33 & 100.0 & 86.95 & \\
\hline
\end{tabular}

Source: Field survey 2007 
and Harijan castes. Brahmins are regarded as the most advanced caste but they are characterized by opposition from husband as well as family members for non adopting the family planning method. Harijan of the village under study (most poor caste) are not adopting this programme mainly due to no knowledge and scareg side effects of various methods of contraception. Total Kumhar respondents have fallen in non users category on account of no adequate knowledge about the birth control methods.

A multi faceted strategy aimed at sustained efforts focusing on safety and beneficial effects of various contraceptives, clearing of misconceptions about side effects of contraceptives by family planning counsellors and equal involvement of both husband and wife as one unit need be formulated to bring out the favourable outcome in terms of contraception use.

\section{CONCLUSION}

Present paper is an attempt to highlight the noticeable change occurred in the social status of various castes especially in Kurmi, Brahmin and Kumhar and awareness of women regarding family planning programme. The relative change in status of caste indicated that the efforts made by the state and central governments have not brought fruitful results in ameliorating the condition of down trodden castes of the society in Gaura village. But the study of Manoj Kumar (2008) on village Arya Nagar, Hisar is positive. The study of Varma and Rohini (2008) on attitude of spouse towards family planning showed that men have positive attitude but seemed to encourage their wives to adopt the family planning methods. Similar situation has also been found in this study. The successful limitation of family size by the couples depends not only on their small family norms but also on their emotional acceptance of family limitation, knowledge of birth control methods, availability of contraceptives, economic costs and more importantly an environment favourable to follow the birth control measures. Second hypothesis with regards to scheduled caste and non scheduled castes got confirmed but in general terms (at individual caste level) it has not been confirmed. The third proposed hypothesis stood unconfirmed.

\section{ACKNOWLEDGMENT}

The authors are thankful to the University Grants Commission, New Delhi for providing the fellowship to Mr. Vimalesh Kumar Singh. Special, thanks are also due to Dr. P. K. Pindi, and Dr. V. K. Mishra for valuable suggestions.

\section{REFERENCES}

IIPS, 1995. National Family Health Survey (MCH and family planning), India 1992-93. Bombay: International Institute for Population Science,.

Institute for Population Sciences and ORC Macro, 2000. National Family Health Survey (NFHS2), 1998-99. Bombay: International Institute for Population Sciences,

International Institute for Population Sciences and Macro International 2007). National Family Health Survey (NFHS-3), Mumbai:International Institute for Population Sciences, 2005-06: India: Volume I,

Jain, A. K. and M. Nag. 1999. Importance of female primary education for fertility reduction in India. Economic and Political Weekly, 21(36): 1602-1608.

Kaur, K. and B. K. Patnaik. 1999. Proportion of Small Family Norm Through Innovative Method. A Report - Centre for Research in Rural \& Industrial Development: Chandigarh.

Khan, M.E., Dastidar, S.K. and Bainathi, S. 1985. Not wanting children yet not practising family planning. The journal of family welfare, XXXII No. 3(12) 8.

Kumar Manoj. 2008. A Study in Social Dynamism of village 'Arya Nagar' in District Hisar, J. Soc. Scie. 16 (2): 121-126

Ministry of Health and Family Welfare. 1998. Family Welfare Programme in India, Year Book, 1996-1997. Department of Family Welfare, Ministry of Health and Family Welfare, New Delhi

Ministry of Health and Family Welfare: National Population Policy, 2000. New Delhi: Department of Family Welfare, Ministry of Health and Family Welfare.

Nag, M. 1984. Some cultural factors affecting costs of fertility regulation. Population Bulletin of the United Nations, 17: 17-38.

National Family Health Survey. 1998-99. http:// www.mohfw.nic.in/fsnfns.htm

Pandey, S. and R. Singh. 2001. Environment, caste and community in family planning knowledge attitude- behaviour relationship. Prachi Journal of Psycho Cultural Dimensions, 17(2): 103-108.

Retherford, R.D. and V. Misra. 1997. Media exposure increases contraceptive use. NFHS. Bulletin No. 7. http//www.mohfw.nic.in/fsnfhs.htm

Ringheim, K. 1993. Factors that determine prevalence of use of contraceptive methods for men. Studies in Family Planning, 24(2): 87-99. 
Shrestha, A., Stoeckel, J. and Taladhar, J.H. 1988. Factors related to non use of contraception among couples with an unmet need for family planning in Nepal, Kathmadhu, Nepal, New Era: 81.

Singh, K.N. 1975. An Approach to the Study of the Morphology of the Indian Village, (pp. 203-215) in R.L. Singh (ed.), Rural Settlement in Monsoon Asia. Varanasi: National Geographical Society of India.

Sinha, A., Kriplani A., Takkar D., Roy K. K. and Banerjee N. 2001. Factors determining the occurrence of unwanted pregnancies. National Medical Journal of India, 14(4): 211-214.

Sriniwas, M.N. 1969. Indian: Social structure, New Delhi, Hindustan Publishing Corporation.
Stash S. 1995. Reason for unmet need in Nepal: An attempt to pick up where fertility surveys leave off, 45 Unpublished.

Varma, G.R. and Rohini, A. 2008. Attitude of spouse towards family planning: A study among Married Men and Women of a Rural community in West Godawari District, A.P., Anthropologist, 10 (1): 71-75.

World Health Organization. 2006 India and Family Welfare Planning, an Overview. South-East Asia Regional Office, World Health Organization, New Delhi.

Yadav, S., Mishra, C.P. and Srivastava, P. 2003. Caste: A major determinant of socio-economic status of rural households. Demography India, 32(10: 123-136. 